\title{
Assessment of the nutritional quality of crop contents of scavenging local chickens in Akwa Ibom state of Nigeria
}

\author{
Kolawole Daniel Afolabi ${ }^{*}$, Eugenes Kelechi Ndelekwute ${ }^{1}$, Okhioma Ahmed $\mathrm{Abu}^{2}$ and Idorenyin Nyong \\ Usoroidem $^{1}$ \\ 1. Department of Animal Science, University of Uyo, Uyo, Nigeria 520003
}

2. Department of Animal Science, University of Ibadan, Ibadan, Nigeria

* E-mail of the corresponding author: kaydafl@,yahoo.com

\begin{abstract}
The nutritional quality of feed resource available to indigenous or local scavenging chickens reared in four villages (Mbiabam-Ibiono, Ekpene-Ukim, Ibiaku-Issiet and Utu-Abak) in Akwa Ibom State, southern Nigeria using their crop contents was assessed. A total of 56 local chickens (cocks and hens) purchased from the four villages were slaughtered, defeathered and eviscerated. Their full crop contents were collected separately, oven dried at $70^{\circ} \mathrm{C}$ to constant weights and subjected to proximate, mineral and vitamin analyses. Data obtained were analyzed using descriptive statistics and ANOVA. The weight of fresh crop contents $(16.5-36.67 \mathrm{~g})$ and their dry matter $(32.27-52.17 \%)$ varied significantly. The crude protein-CP $(13.27-14.18 \%)$, ether extract $(5.50-$ $5.95 \%)$, ash $(3.57-3.98 \%)$ and the crude fibre $(3.10-3.45 \%)$ levels of the crop contents also varied significantly across villages. The $\mathrm{CP}$ and apparent metabolizable energy levels were lower than the reported levels and requirements for optimal performance of Nigerian indigenous chicken. Minerals (mg/100g) determined were calcium $(233.30-235.8)$, iron $(11.70-12.13)$, potassium $(33.33-36.17)$, magnesium (43.0 $46.67)$, manganese $(0.043-0.053)$ and phosphorus $(170.8-180.0)$; while vitamins $(\mathrm{mg} / 100 \mathrm{~g})$ measured were ascorbic acid $(14.55-14.92)$, thiamine $(0.082-0.118)$, riboflavin $(0.128-0.163)$, niacin $(2.20-2.36)$ and $\beta$ carotene $(36.87-43.33)$ that varied significantly except for calcium and magnesium that were similar. The minerals and riboflavin levels in the scavenged feed could not meet the birds' requirements. Local birds' diet need to be supplemented daily with concentrate or ration from locally available feed ingredients to meet their nutritional requirements for optimal performance. Awareness creation on the importance of supplementary feeding to alleviate poverty and malnutrition among the subsistent rural poultry farmers is vital.
\end{abstract}

Keywords: Feed resource, proximate, minerals and vitamin composition, nutrient requirements

DOI: $10.7176 /$ ALST/76-06

Publication date:November $30^{\text {th }} 2019$

\section{Introduction}

About $80 \%$ of the Africa's poultry population is found in the traditional production systems (Sonaiya, 2004). Local or indigenous chicken has been reared immemorial in the traditional rural/village farming system as a major source of animal protein (meat and eggs), income, entertainment of visitors and for socio-cultural purposes during festivals, ceremonies and sacrifices/rituals as there are no suitable substitutes for use. Despite their population and importance, their productivity never supersedes those of exotic or hybrid breeds due to the management system characterized by extensive or scavenging nature with fluctuating sub-optimal housing, environmental, health, nutrition and security regimes. Despite their genetic limitations the nutrients requirements of Nigerian local fowl for optimal performance/productivity have been determined by some researchers (Afolabi, 2009; Longe, 2006; Ezeokeke, 2004) in order to harness their full potentials. There is the need therefore to assess and compare what the chicken consume through scavenging and supplementation (if any) with their nutrient requirements in order to judge their performance and proffer suitable advice that will enhance their productivity. This study therefore assessed the nutritional quality of feed resource available to indigenous or local scavenging chickens reared in four villages (Mbiabam-Ibiono, Ekpene-Ukim, Ibiaku-Issiet and Utu-Abak) in Akwa Ibom State of Nigeria by evaluating the chemical composition of their crop contents.

\section{Materials and methods}

2.1 Location

The study was carried out on indigenous or local scavenging chickens reared on in four locations/villages in 
Akwa Ibom state. The villages were Mbiabam Ibiono village in Ibiono Ibom Local Government Area, Ekpene Ukim and Ibiaku Issiet in Uruan Local Government Area and Utu-Abak village in Abak Local Government Area of Akwa Ibom State, Nigeria. Akwa Ibom State is between latitude $04^{\circ} 32^{\circ}$ and $05^{\circ} 33^{\prime} \mathrm{N}$ and longitude $07^{\circ} 25^{\circ}$ and $08^{\circ} 23^{\prime} \mathrm{E}$, characterized by a humid climate with a mean annual rainfall of $2115 \mathrm{~mm}$, binomial in nature, a mean of monthly temperature of $27^{\circ} \mathrm{C}$ and a mean relative humidity of $81.60 \%$ (Udosen, 2002).

The communities were essentially agrarian; cultivating food crops such as corn, cassava and yam. Chickens, goats and sheep are common livestock kept. The local birds were reared on traditional scavenging management system which allowed them to move freely, scavenge at day time and are back to owners care without any supplemental feed. Some roost on roof tops and tree tops.

\subsection{Experimental birds, chemical analysis and calculations}

A total of 56 local cocks and hens purchased from the four villages on different days were slaughtered by severing the jugular vein at the joint between the skull and the cervical bones. The birds were carefully stunned, to avoid stress, slaughtered, dipped in hot water $\left(70^{\circ} \mathrm{C}\right)$ for few seconds and defeathered before they were eviscerated in the laboratory. Full crop contents were obtained from the birds, emptied into aluminum foil separately and left in the oven to dry at $70^{\circ} \mathrm{C}$ to a constant weight. The samples were subjected to proximate, mineral and vitamin analyses (AOAC, 2010). An indirect method of Wiseman (1987) was used to calculate true metabolizable energy $(\mathrm{TME})$ as TME $(\mathrm{kcal} / \mathrm{kg} \mathrm{DM})=3951+54.4 \mathrm{EE} \%-88.7 \mathrm{CF} \%-40.8$ ash\%. AME was determined on the basis of TME contents assuming that TME was $8 \%$ higher than the AME as TME is $5-10 \%$ higher than AME (Wiseman, 1987).

\subsection{Statistical analysis}

Data obtained from the energy content, proximate, vitamins and mineral content of the crop contents were subjected to ANOVA of GENSTAT (2005). Treatment means were separated with the Duncan multiple range test option of the software.

\section{Results and Discussion}

The chemical composition of crop contents of local chickens in four villages in Akwa Ibom state is as shown in Table 1 below. The weight of fresh crop contents varied significantly from $16.5 \mathrm{~g} / \mathrm{birds}$ for birds of Ekpene-Ukim to $36.67 \mathrm{~g}$ in Ibiaku-Issiet which was the significantly $(\mathrm{p}<0.05)$ highest value obtained. The weight of crop contents of local birds in Mbiabam-Ibom (20.6g/bird) was similar to those of Ekpene-Ukim (16.5g/bird) and Utu-Abak $(26.83 \mathrm{~g} / \mathrm{bird})$. The weight of the fresh crop content is a function of the quantity of available scavengeable feed resource in the community and the availability of water for the animals to drink. Many of the local chicken rearers provide little or no water for the birds as they allow them to roam to find feed and water for themselves. The values obtained for weights of fresh crop content in this study were within the range of values $(20.12+10.82-21.8+15.16 \mathrm{~g} / \mathrm{bird})$ reported (Hayet et al., 2016) for scavenging indigenous chicken of chekorsa district of Jimma zone during the dry period.

The percentage dry matter (DM) of fresh crop content of local chicken in Akwa Ibom state varied significantly. The significantly highest DM (52.17\%) was obtained for birds of Utu-Abak followed by those of Ekpene-Ukim (43.64\%), Mbiabam-Ibiono (41.76\%) and those of Ibiaku-Issiet (32.27\%) in a descending order. The \% DM of crop content of scavenging local chicken obtained in this study $(32.27-52.17 \%)$ is within the range of values $(44 \pm 36.8$ - 51.4. $\pm 6.39 \%)$ reported for local birds of Ethiopia and Bangladesh (Hayet et al., 2016; Rashid et al., 2005). Hanyani (2012) had reported the dry matter of crop content of scavenging local chicken in spring season of Eastern Cape, South Africa to be $60.10 \%$. Also the percentage DM of oven dried crop content were similar for scavenging local chicken of Mbiabam-Ibiono village (90.62\%), Ekpene-Ukim (90.50\%) and Ibiaku-Issiet $(90.48 \%)$ villages but significantly $(\mathrm{p}<0.05)$ higher than what obtained $(90.15 \%)$ for those Utu-Abak village. Values obtained were within the range of values $(90.12+1.36-94.18+0.91 \%)$ reported by Hayet et al., (2016) and Momoh et al., (2010).

The crude protein content of the crop content of scavenging chicken $(13.27-14.18 \%)$ varied significantly. The significantly $(\mathrm{p}<0.05)$ highest protein content was obtained for the crop content of local birds from Utu-Abak village $(14.18 \%)$ which was similar to what obtained for those of Mbiabam-Ibiono village (14.10\%). Protein content of the crop content of scavenging local birds from Ibiaku-Issiet village $(13.85 \%)$ were significantly lower than those of Utu-Abak village, though similar to those of Mbiabam village, but significantly higher than what obtained for local birds of Ekpene-Ukim (13.27\%) village. The CP content or concentration in the feed consumed by the scavenging local chicken across villages $(13.03-14.18 \%)$ were below the requirements for local hens for protein $(20 \% \mathrm{CP})$ earlier reported by Afolabi (2009) and this will adversely affect the growth and consequently the meat and egg production from local birds. Kingori et al., (2003) in Kenya had also reported that 
the crude protein requirement for indigenous chickens to be between $16-20 \%$. The recommended protein requirement for Nigeria indigenous chicken at the chick starter, finisher and layer stages had been reported to be 22, 17 and 21\% respectively by Ezeokeke, (2004) and Longe, (2006).

The ash or mineral component of scavenging chicken crop content were similar for the villages studied (3.87 $3.98 \%$ ) except for those of Ekpene-Ukim (3.57\%) that were significantly lower than others. The amount of ash from the crop content in this study was very low and lower than. 12.3. \pm 6.71 and $12.4 . \pm 5.51 \%$ of ash indicated by Rashid et al; (2004) for grower and layer scavenging indigenous chickens of Seka Chekorsa of Ethiopia. Higher value for ash of local chicken crop contents $(8.40$ - 26.15\%) were also reported by Hayet et al., (2016), Raphulu et al., (2015), Momoh et al., (2010), Goromela et al., (2008) for scavenging indigenous chicken in North central Nigeria, south Africa, Ethiopia and Tanzania. The variation in ash content can be attributed to the type of soil, level of humus on the top soil and the inclusion of sand and other inorganic elements that were quantified as crude ash during proximate analysis.

The crude fibre component of scavenging local birds' crop content $(3.1-3.45 \%)$ varied significantly. The crude fibre of crop contents of birds from Mbiabam (3.45) was similar to those of Utu-Abak (3.4\%) but significantly higher than those of Ekpene - Ukim (3.1\%) and Ibiaku-Issiet (3.2\%) that were also similar. The crude fibre levels obtained in this study were lower than (5\%) that is recommended (Feltwell and Fox, 1978) for commercial layer rations, though within the range of values $(3.29-3.69 \% \mathrm{CF})$ reported (Raphulu et al., 2015) for crop content of local birds in rural villages of the Venda region of South Africa. The values were also lower than the values (3.87 - 11.92\% CF) reported (Rashid et al 2004; 2005); Hayet et al., 2016; Momoh et al; 2010; Goromela et a1; 2008; for scavenging indigenous chickens of Bangladesh, North central Nigeria, Ethropia, Tanzania at grower and layer stages. The lower crude fibre in the feed consumed by the local chicken can be attributed to their scavenging experience or better foraging habits that enable them to select less fibrous feed materials.

The crude fat or either extract of crop content from local birds from three of the villages studied $(5.77-5.95 \%)$ were similar and significantly higher than what obtained (55\%) for Ekpene - Ukim village. It was observed that the major sources of fat from the scavenged feed were from the oil palm fruit and insects because the birds were seen pecking insects, oil palm fruits and by products from processed palm fruit. Oil palm is one of the major perennial cash crops grown in southern part of Nigeria. The value obtained for crude fat level of crop content is similar to values reported $(5.12 \pm 16-6.55 \pm 3.47 \%)$ reported for the crop content of indigenous chicken of North central Nigeria. However the values were higher than the range of values $(2.97-5.09 \%$ EE) reported in other works (Hayet et al., 2016; Rashid, et al., 2004 and 2005; Raphulu et al., 2015) in other countries. The ether extract component of feed is a good source of energy, fatty acids especially the essential fatty and (linoleic acid) for poultry growth, development and optimal production.

The Nitrogen free extract-NFE $(62.82-65.07 \%)$ which is the soluble carbohydrate component of the feed consumed varied significantly. The significantly highest value $(65.07 \%)$ was obtained for the crop content of local chickens from Ekpene-Ukim, followed by those of Ibioku-Issiet (63.80\%) and Mbiabam-Ibiono (63.15\%), and the least value was obtained for those of Utu-Abak (62.82\%). The NFE component of the crop content from Mbiabam-Ibiono was found to be similar to those of Ibiaku-Issiet and Utu-Abak villages. The results showed that the feed scavenged by these chickens were rich in carbohydrate which could come from grains and tubers that are grown in these communities. This also explains the higher Apparent Metabolizable Energy-AME (3502 $-3523 \mathrm{kcal})$ and true ME $(3807-3830 \mathrm{kcd} / \mathrm{kg})$. The $\%$ NFE in crop content of scavenging chicken obtained in this study corroborate the findings $(53.5-64.9 \%$ NFE) of Raphulu et al; (2010) in South Africa, and Goromela et al., (2008) in Tanzania but higher than $44.73-56.26 \%$ NFE reported by Hayet et al., 2016 and Momoh et al., 2010 for indigenous chickens of Ethiopia and North Central Nigeria.

The total carbohydrate $(66.22-68.17 \%)$ followed the same trend as NFE. The AME of the crop content (3503$3523 \mathrm{kcal} / \mathrm{kgDM}$ ) were similar among local birds across the villages studied. The AME values obtained were higher than $3061.67-3217.02 \mathrm{kcal} / \mathrm{kgDM}$ and $2023.0 \pm 398-2082.80 \pm 855$ reported for energy values of crop content of indigenous chickens of south Africa and Ethiopia respectively by Rhaphulu et al., (2016) and Hayet et al., (2016). Ezeokeke, (2004) had recommended AME levels of 3000kcal $/ \mathrm{kgDM}$ for Nigerian indigenous chicken at chick starter and finisher phases while Afolabi (2009) reported optimal laying performance for Nigerian local hen fed diet containing $2700 \mathrm{kcal} / \mathrm{kgDM}$.

The True Metabolizable Energy (TME) of the crop content $(3807-3830 \mathrm{kcal} / \mathrm{kgDM})$ varied significantly. The TME obtained for crop content of Ekpene-Ukim birds $(3830 \mathrm{kcal} / \mathrm{kgDm})$ was significantly higher than those of other villages, though similar to those of Utu-Abak village $(3822 \mathrm{kcal} / \mathrm{kgDM}$. The TME obtained for local birds 
of Mbiabam-Ibiono (3807kcal/kgDM), Ibiaku-Issiet (3808kcal/kg) and Utu-Abak (3822 kcal/kg DM) were similar. The TME values for indigenous chickens' crop contents obtained in the study were higher than those earlier reported $(2352-29115.87 \mathrm{kcal} / \mathrm{kgDM})$ by other authors (Momoh et al., 2010; Rashid et al., 2014; Gomorola et al., 2008) for indigenous chickens of North central Nigeria, Bangladesh and Tanzania.

Table 1: Chemical composition of crop content of local chicken in four villages in Akwa Ibom state, southern Nigeria.

\begin{tabular}{|c|c|c|c|c|c|c|}
\hline $\begin{array}{l}\text { Village } \\
\text { Village Name }\end{array}$ & Mbiabam- & $\begin{array}{l}2 \\
\text { Ekpene- }\end{array}$ & $\begin{array}{l}3 \\
\text { Ibiaku- }\end{array}$ & $\begin{array}{l}4 \\
\text { Utu-Abak }\end{array}$ & & \\
\hline L G A. & $\begin{array}{l}\text { Ibiono } \\
\text { Ibom }\end{array}$ & Uruan & Uruan & Abak & SEM & P. Value \\
\hline $\begin{array}{l}\text { Parameters: } \\
\text { Wt. of Fresh crop content (g) }\end{array}$ & $20.6^{\mathrm{bc}}$ & $16.5^{\mathrm{c}}$ & $36.67^{\mathrm{a}}$ & $26.83^{\mathrm{b}}$ & 0.33 & $<0.001$ \\
\hline DM of fresh crop content $(\%)$ & $41.76^{\mathrm{b}}$ & $43.64^{\mathrm{b}}$ & $32.27^{\mathrm{c}}$ & $52.17^{\mathrm{a}}$ & 0.62 & $<0.001$ \\
\hline $\begin{array}{l}\text { DM of Oven dried crop content } \\
(\%)\end{array}$ & $90.62^{\mathrm{a}}$ & $90.50^{\mathrm{a}}$ & $90.48^{\mathrm{a}}$ & $90.15^{\mathrm{b}}$ & 0.10 & 0.021 \\
\hline Ash $(\%)$ & $3.97^{\mathrm{a}}$ & $3.57^{\mathrm{a}}$ & $3.87^{b}$ & $3.98^{\mathrm{a}}$ & 0.04 & $<0.001$ \\
\hline Crude Protein $(\%)$ & $14.10^{\mathrm{ab}}$ & $13.27^{\mathrm{c}}$ & $13.85^{\mathrm{b}}$ & $14.18^{\mathrm{a}}$ & 0.10 & $<0.001$ \\
\hline Crude Fibre (\%) & $3.45^{\mathrm{a}}$ & $3.10^{\mathrm{b}}$ & $3.20^{\mathrm{b}}$ & $3.40^{\mathrm{a}}$ & 0.06 & 0.003 \\
\hline Ether Extract (\%) & $5.95^{\mathrm{a}}$ & $5.50^{\mathrm{b}}$ & $5.77^{\mathrm{a}}$ & $5.93^{\mathrm{a}}$ & 0.06 & $<0.001$ \\
\hline Nitrogen Free Extract (\%) & $63.15^{\mathrm{bc}}$ & $65.07^{\mathrm{a}}$ & $63.80^{\mathrm{b}}$ & $62.82^{\mathrm{c}}$ & 0.24 & $<0.001$ \\
\hline Total Carbohydrate (\%) & $66.60^{\mathrm{bc}}$ & $68.17^{\mathrm{a}}$ & $67.00^{\mathrm{b}}$ & $66.22^{\mathrm{c}}$ & 0.18 & $<0.001$ \\
\hline Apparent ME (Kcal/kg) & 3502 & 3523 & 3503 & 3516 & 7.54 & 0.32 \\
\hline True ME (Kcal/kg) & $3807^{\mathrm{b}}$ & $3830^{\mathrm{a}}$ & $3808^{b}$ & $3822^{\mathrm{ab}}$ & 4.81 & 0.007 \\
\hline
\end{tabular}

${ }^{\mathrm{a}-\mathrm{c}}$ Means in the same row for each parameter with different superscripts are significantly different $(\mathrm{p}<0.05)$. $\mathrm{SEM}=$ Standard error of means; $\mathrm{P}$ value = Probability value; $\mathrm{DM}=$ Dry matter; $\mathrm{ME}=$ Metabolizable Energy; LGA $=$ Local Government Area.

The mineral and vitamin concentrations of crop content of local birds in four villages in Akwa Ibom state of Nigeria is as shown in table 2 below. The calcium (233.3-235.8mg/100gDM) and magnesium (43.0 $46.67 \mathrm{mg} / 100 \mathrm{gDM}$ ) component of the crop content of the scavenging local chickens in the four villages was similar. These values were lower than the corresponding values $(450-1490 \mathrm{mgCa} / 100 \mathrm{gDM})$ and $220 \mathrm{mgMg} / 100 \mathrm{gDM}$ ) obtained in previous studies (Rhaphulu et al., 2005, Hayet et al., 2016; Momoh et al., 2010; Rashid et al., 2004, Goromela et al., 2008). The $\mathrm{Ca}$ and $\mathrm{Mg}$ content in the feed consumed by the birds did not meet the requirements (NRC, 1994) for layer hen $(3250 \mathrm{mg} / 100 \mathrm{gDM}$ of $\mathrm{Ca}$ and $500 \mathrm{mg} \mathrm{Mg} / 100 \mathrm{gDM})$ and broilers $(800-1000 \mathrm{mg} \mathrm{Ca} / 100 \mathrm{gDM}$ and $600 \mathrm{mgMg} / 100 \mathrm{gDM})$. Deficiency in the dietary concentrations of calcium can results in poor growth, rickets and thin-shelled egg or shell-less eggs in layers. A diet deficient in magnesium leads to slow growth, brief convulsion that can lead to a coma or death in chicks, rapid decrease in blood magnesium levels, withdrawal of magnesium from bone, decline in egg production, reduced hatchability, coma or death (Olomu, 1995; McDonald et al., 1995). Increasing Ca and phosphorus content of the diet corrects $\mathrm{Mg}$ deficiency. A calcium concentration of approximately $8.8 \mathrm{~g} / \mathrm{kgDM}$ for broilers and $35 \mathrm{~g} / \mathrm{kgDM}$ for Leghorn layer was recommended by Dana et al., (2008) at low dietary phosphorus levels $(3.5 \mathrm{~g}$ and $2.8 \mathrm{~g}$ of non-phytin $\mathrm{P} / \mathrm{kg}$ feed respectively). Payne (1990) and Mwalusanya et al., (2002) also noted that adult laying hens tends to select feedstuffs with higher levels of calcium than other chickens because of higher calcium needed to synthesize the eggshell.

The phosphorus content of the feed scavenged by local birds in this study was similar for birds from MbiabamIbiono (180mg/100g), Ibiaku - Issiet (179.2mg/100g) and Utu-Abak (176.7mg/100g) villages. Birds from Ekpene-Ukim consumed significantly lower phosphorus $(170 \mathrm{mg} / 100 \mathrm{~g})$ in their diet, though not significantly different from those of Utu-Abak. The phosphorus levels obtained were within the range of values $(140 \pm 60-$ $530 \mathrm{mgP} / 100 \mathrm{~g} 100 \mathrm{DM}$ ) reported for crop contents of local birds of North central Nigeria by Momoh et al., (2010). However, the phosphorus content of local birds diet in the study is lower than what obtained (310 - 
680mgP/100DM) in other studies (Rashid et al., 2004 and 2005; Goromela et al., 2008; Raphulu et al., 2015; and Hayet et al; 2016). The phosphorus content of the feed consumed by birds in four villages of Akwa Ibom state of Nigeria were also lower than the requirements for broilers $(0.3-0.45 \%$ or $300-450 \mathrm{mgP} / 100 \mathrm{gDM})$ and layers $(0.25-0.35 \%$ or $250-350 \mathrm{mgP} / 100 \mathrm{gDM})$ recommended by NRC (1994).

The transitional element iron $(11.7 \mathrm{o}-12.13 \mathrm{mgFe} / 100 \mathrm{DM})$ and manganese $(0.043-0.053 \mathrm{mgFe} / 100 \mathrm{gDM})$ component of the feed consumed by the scavenging local birds as indicator of their crop content varied significantly $(\mathrm{p}<0.05)$, low and cannot meet the requirements of layer birds $(45-56 \mathrm{mgFe} / 100 \mathrm{gDM}$ and 20 $25 \mathrm{mgMn} / 100 \mathrm{gDM})$ and broilers $(80 \mathrm{mgfe} / 100 \mathrm{gDM}$ and $60 \mathrm{mgMn} / 100 \mathrm{gDM})$ for these trace minerals $(\mathrm{Fe} \& \mathrm{Mn})$ as reported by NRC (1994). Low concentrations of iron and manganese may impair birds' production and reproduction capacity. Low iron concentration can lead to non-deficiency symptomized by anemia or reduction in the size of red blood cells and low hemoglobin (MacDonald et al., 1995). On the other hand deficiency of Mn in embryos can lead to shortening of the long bones, parrot beak and wing down (Olomu, 1995; McDonald et al., 1995).

Values obtained for potassium content of the feed consumed by scavenging indigenous chickens in this study $(33.33$ - 36.17mgK/100gDM) varied significantly but lower than the recommended values for broilers (300mgK/100gDM) and laying hens (150mgK/100gDM) optimal performance (NRC, 1994).

Considering lower levels of macro trace minerals in the diet of scavenging indigenous chickens, there is the need for supplementation of these minerals as supplemental feed or mash to improve the nutritional status of these birds to improve and optimize their productivity potentials. The thiamine $(0.082-0.12 \mathrm{mg} / 100 \mathrm{~g})$, Riboflavin $(0.13-0.16 \mathrm{mg} / 100 \mathrm{~g})$ and Niacin $(2.20-2.36 \mathrm{mg} / 100 \mathrm{~g})$ concentrations in the crop contents of scavenging local chickens across the villages varied significantly. The values with the exception of Riboflavin (Vitamin $\left.\mathrm{B}_{2}\right)$ met the requirements of while leghorn layer birds $(0.07-0.088 \mathrm{mg}$ thiamine $/ 100 \mathrm{~g}$ of feed; $0.25-0.36 \mathrm{mg}$ Riboflavin $/ 100 \mathrm{~g}$ and $1.0-1.25 \mathrm{mg}$ niacin $/ 100 \mathrm{~g}$ ) but lower than the values recommended (NRC, 1994) to meet the requirements $(0.18 \mathrm{mg}$ thiamine $/ 100 \mathrm{~g} ; 0.3-0.36 \mathrm{mg}$ Riboflavin $/ 100 \mathrm{~g}$, and $2.5-3.5 \mathrm{mg}$ niacin $/ 100 \mathrm{~g}$ of feed $)$ of broiler chicken for optimal performance.

Thiamine is a co-factor for several enzymes catalyzing decarboxylation and transketolation type reactions, and its deficiency leads to nervous symptoms such as ataxia, and awkward backward flexions of the head and neck (Olomu, 1995; McDonald et al., 1995); high embryonic mortality prior to hatching and polyneuritis in hatched chicks (Olomu, 1995; McDonald et al., 1995; Charles et al., 1972). Deficiency of riboflavin in chicken usually affects the embryonic development (as it can head to the death of embryos in incubation with the appearance of shortened limbs, malformed mandibles, and clubbing of the down, and largely dwarfism with clubbed down.

Niacin on the other hand acts as a cofactor to many enzymes in glycolysis, lipogenesis and energy metabolism; and its deficiency symptoms in chicken includes inflammation of the oral cavity and occasional poor feathering; dermatitis and porosis- a malformation of the bones (Olomu, 1995; McDonald et al., 1995; Briggs et al., 1943). The B-carotene (vitamin A precursor) concentration in the crop content or feed scavenged by local chickens in Mbiabam-Ibiono $(42.50 \mathrm{mg} / 100 \mathrm{~g})$, and Utn-Abak $(73.33 \mathrm{mg} / 100 \mathrm{~g})$ villages were similar and significantly higher than what obtained for those of Ekpene-Ukim $(36.87 \mathrm{my} / 100 \mathrm{~g})$. The birds had ample access to green leaves and vegetables which are good sources of B-carotene, a precursor of vitamin A. NRC (1994) however recommended $3,000-3,750 \mathrm{IU}$ of $\beta$-carotene requirement for laying hens.

The ascorbic acid (vitamin C) obtained in the crop content of local birds in the study $(14.55-14.92 \mathrm{mg} / 100 \mathrm{~g}$ ) varied significantly across villages. This showed that the chickens can get additional ascorbic acid from scavenging partly from leaves and fruits. Vitamin $\mathrm{C}$ is not considered to be required dietary nutrient in poultry because it can be synthesized by poultry (NRC, 1994). Still it plays a vital role in chickens' good health as it was reported to increase its performance and reduces the mortality rate of broilers chickens (Olukosi, 2002).

The protein, AME, riboflavin and the determined mineral element levels in the scavenged feed consumed by local chickens in the selected four villages in Akwa Ibom state of Nigeria could not meet the birds' requirements for optimal productivity and this explains their low performance compared to the exotic birds reared intensively with standard management. Robert and Gunarantne (1992) had reported low productivity and reproductivity in scavenging chickens and attributed the cause to a number of factors like sub-optimal management, lack of supplementary feed, low genetic potentials and diseases. They however attributed much of the low performance of indigenous chicken to poor scavenging feed resource base and concluded that if scavenging feed resource is improved, productivity and reproductivity would be increased and this also depend on the intrinsic factors such 
as seasonal variables and level of predation, health, scavenging behavior, age and physiological status of the bird. Therefore scavenging local birds' diet need to be supplemented daily with concentrate or ration from locally available feed ingredients to meet their nutritional requirements for optimal performance, and the awareness should be created and disseminated among rural dwellers to improve their income and livelihood.

Table 2: Mineral and vitamins (mg/100g) composition of crop content of local chickens in four villages Akwa Ibom state, southern Nigeria.

\begin{tabular}{|c|c|c|c|c|c|c|}
\hline Village & 1 & 2 & 3 & 4 & & \\
\hline Village Name & Mbiabam & Ekpene & Ibiaku & Utu-Abak & SEM & P. Value \\
\hline L. G. A. & $\begin{array}{l}\text { Ibiono } \\
\text { Ibiono Ibom }\end{array}$ & $\begin{array}{l}\text { Ukim } \\
\text { Uruan }\end{array}$ & $\begin{array}{l}\text { Issiet } \\
\text { Uruan }\end{array}$ & Abak & & \\
\hline
\end{tabular}

\begin{tabular}{lllllll}
\hline Parameters: & & & & & \\
Calcium & 235.8 & 234.2 & 233.3 & 235.8 & 1.43 & 0.528 \\
Iron & $12.13^{\mathrm{a}}$ & $11.70^{\mathrm{b}}$ & $11.83^{\mathrm{ab}}$ & $12.13^{\mathrm{a}}$ & 0.13 & 0.062 \\
Potassium & $35.0^{\mathrm{ab}}$ & $33.33^{\mathrm{b}}$ & $34.83^{\mathrm{ab}}$ & $36.17^{\mathrm{a}}$ & 0.6 & 0.103 \\
Magnesium & 45.00 & 43.0 & 45.83 & 46.67 & 1.54 & 0.485 \\
Manganese & $0.050^{\mathrm{ab}}$ & $0.043^{\mathrm{b}}$ & $0.052^{\mathrm{ab}}$ & $0.053^{\mathrm{a}}$ & 0.003 & 0.095 \\
Phosphorus & $180.0^{\mathrm{a}}$ & $170.8^{\mathrm{b}}$ & $179.2^{\mathrm{a}}$ & $176.7^{\mathrm{ab}}$ & 2.19 & 0.032 \\
Ascorbic acid (Vit. C) & $14.73^{\mathrm{ab}}$ & $14.55^{\mathrm{b}}$ & $14.58^{\mathrm{b}}$ & $14.92^{\mathrm{a}}$ & 0.10 & 0.640 \\
B-carotene (Vit. A) & $42.50^{\mathrm{a}}$ & $36.87^{\mathrm{b}}$ & $40.00^{\mathrm{ab}}$ & $43.33^{\mathrm{a}}$ & 1.46 & 0.018 \\
Niacine (Vit. B3) & $2.36^{\mathrm{a}}$ & $2.20^{\mathrm{b}}$ & $2.33^{\mathrm{a}}$ & $2.358^{\mathrm{a}}$ & 0.02 & $<0.001$ \\
Riboflavin (Vit. B2) & $0.16^{\mathrm{a}}$ & $0.128^{\mathrm{c}}$ & $0.14^{\mathrm{b}}$ & $0.16^{\mathrm{ab}}$ & 0.005 & $<0.001$ \\
Thiamine (Vit. B1) & $0.12^{\mathrm{a}}$ & $0.08^{\mathrm{b}}$ & $0.098^{\mathrm{b}}$ & $0.118^{\mathrm{a}}$ & 0.006 & $<0.001$ \\
\hline
\end{tabular}

${ }^{\mathrm{a}-\mathrm{c}}$ Means with different superscripts within a row are significantly different $(\mathrm{p}<0.05)$.

$\mathrm{SEM}=$ Standard error of mean; $\mathrm{P}$ value $=$ probability value; $\mathrm{LGA}=$ Local Government Area

\section{Conclusion}

The nutrient (energy, protein, micro and macro elements) levels of crop content of indigenous chickens in the four villages studied were below the requirements for the scavenging local chickens and inadequate for optimal performance. This may be attributed to the lack of knowledge about the importance of supplementary feeding and poverty associated with lack of credit to the subsistent rural poultry sector.

There is urgent need to develop awareness on basic daily supplementary rations with the use of locally available feed ingredients to attain maximal or optimal productivity and more returns from the enterprise to alleviate poverty and malnutrition.

\section{References}

Afolabi, K. D. (2009). Energy and protein requirements of the Nigerian Local Fowl (Gallus domesticus) fed palm kernel cake-based Diets. Ph.D Thesis, Department of Animal Science, University of Ibadan, Nigeria 176p.

AOAC International (2010). Official Methods of Analysis, $18^{\text {th }}$ Edition, Association of Official Analytical Chemists International, Gaithersburg, MD. http://www.aoac.org

Briggs, G. M., Juckey, T. D., Teply, L. J., Elvehjem, C. A. and Hart, E. B. (1943). Studies on nicotinic acid deficiency in the chicks. Journal of Biology and Chemistry, 148:517.

Charles, O. W., Roland, D. A.. and Edwards, H. M. (1972). Thiamine deficiency identification and treatment in commercial turkeys and Coturnix quail. Poultry Science, 51: 419.

Dana, N., Liesbeth, H., Vander, W., Tadelle, D. and Johan, A. M. (2008). Production objectives and trait preferences of village poultry producers of Ethiopia: implications for designing breeding schemes utilizing indigenous chicken genetic resources. Tropical Animal Health and Production 42:1519-1529.

Olukosi, O. A. (2002). A multisystem approach to the determination of the nutritional base for scavenging family poultry. M. Phil Thesis, Obafemi Awolowo University, Ile Ife, Nigeria.

Ezeokeke, C. (2004). Studies on the requirement for energy, protein and feed additives by the local fowl (Gallus domesticus) Ph.D. Thesis, Department of Animal Science, University of Ibadan, Ibadan. Nigeria.

Feltwell, R. and Fox, S. (1978). Practical Poultry Feeding. Faber and Faber Ltd., London, 36-49.

Genstat (2005). Genstat for Windows. Genstat Release 8.1, 7th Edition Lawes Agricultural Trust Rothamsted Experimental Station.

Goromela, E. H, Kwakkel, R. P., Verstegen, M. W. A. and Katule, A. M. (2008). Effect of season and farming system on the quantity and nutritional quality of scavengeable feed resources and performance of village poultry in central Tanzania. Journal of Cell and Animal Biology, 2(3):63-71. 
Gunaratne, S. P., Chandrasiri, A. D. N., Hemalatha, W. A. P. and Roberts, J. A. (1992). Productivity and nutrition of village chickens in Sri Lanka. In: Newcastle Disease in Village Chickens, (Spradbrow, P.B., Ed), Australian Centre for International Agricultural Research, Canberra, Proceedings No 39:144-148.

Hanyani, C. T. (2012). Effect of full and semi-scavenging rearing systems on crop contents and the quality of meat from village chickens during the spring season of eastern cape, south Africa a dissertation submitted in fulfilment of the requirements for the degree Master of Science in Agriculture (Animal Science), Department of Livestock and Pasture Science Faculty of Science and Agriculture, University of Forte Hare, Alice Town, South Africa.

Hayat, N., Solomon, D. and Meseret, M. (2016). Chemical Composition of Scavenging Feed Resource of Indigenous Chickens, Asian Journal of Animal Science, 18(3):182-188.

Kingori, A. M, Wachira, A. M., Tuitoek, J. K. (2003). Indigenous Chicken Production in Kenya: A Review. International Journal of Poultry Science, 9 (4): 309-316.

Longe, O. G. (2006). Poultry: Treasure in a chest. An Inaugural lecture delivered at the University of Ibadan, Ibadan on 24th August 2006. Published by Ibadan University press, Ibadan, Nigeria. 42pp.

McDonald, P., Edwards, R. A., Greenhalgh, J. F. D. and Morgan, C. A. (1995). Animal Nutrition. $5^{\text {th }}$ Edition. Pearson Education Limited, Edinburgh Gate, Harlow Essex CM20 2JE, UK. 607pp.

Momoh, O. M., Egahi, J. O., Ogwuche, P. O. and Etim, V. E. (2010). Variation in nutrient composition of crop contents of scavenging local chickens in North Central Nigeria. Agriculture and Biology Journal of North America, 1(5): 912-915 doi:10.5251/abjna.2010. ScienceHuß, http://www.scihub.org/ABJNA .

Mwalusanya, N. A., Katule, A. M., Mutayoba, S. K., Minga, U. M., Mtabo, M. A., Olsen, J. E. (2002). Nutrient status of crop contents of rural scavenging local chickens in Tanzania. British Poultry Sciences, 43: 6469. 98.

NRC. (1994). Nutrient Requirements of Poultry. Ninth revised edition National Academics of Science, Washington D.C., USA.

Olomu, J. M. (1995). Monogastric Animal Nutrition. First Edition, Jachem Publication, Benin City, Nigeria, 320 pp.

Payne, W. J. A. (1990). An Introduction to Animal Husbandry in the Tropics. 4th ed. Longman Scientific and Technical, Essex and New York. pp. 684-744

Raphulu, T., Jansen van Rensburg, C. and van Ryssen, J. B. J. (2015). Assessing nutrient adequacy from the crop contents of free-ranging indigenous chickens in rural villages of the Venda region of South Africa. South African Journal of Animal Science, 45:143-152. DOI: 10.4314/sajas.v45i2.5

Rashid, M. M., Islam, M. N., Roy, B. C., Jakobsen, K., Lauridsen, C. (2005). Nutrient concentrations of crop and gizzard contents of indigenous scavenging chickens under rural conditions of Bangladesh. Livestock Research for Rural Development, 17(2). http://www.cipav.org.co/lrrd/lrrd17/2/rash17016.htm. Accessed 12th June 2011

Rashid, M., Chandra, B. and Asaduzzaman, V. (2004). Chemical composition of crop contents of local scavenging chickens. Pakistan Journal of Nutrition, 3(1): 26-28.

Sonaiya, E. B. (2004). Direct assessment of nutrient resources in free range and scavenging systems. Regional report: In: World's Poultry Science Journal, 60:523-535.

Udosen, C. E. (2002). Rainfall Analysis and Forecasting in Akwa Ibom State. Unwana graphics press, USA.

Wiseman J. (1987). Feeding of Non-ruminant Livestock. Butterworth, London, UK. pp. 9-13. 